\title{
Narrativity in The Thousand and One Nights
}

\author{
Karam Nayebpour* \\ Department of English Language and Literature, Karadeniz Teknik Üniversitesi (KTÜ), Trabzon 61080, Turkey
}

Corresponding Author: Karam Nayebpour, E-mail: knayebpour@gmail.com

\author{
ARTICLE INFO \\ Article history \\ Received: June 09, 2017 \\ Accepted: July 27, 2017 \\ Published: August 31, 2017 \\ Volume: 8 Issue: 4 \\ Advance access: August 2017 \\ Conflicts of interest: None \\ Funding: None \\ Key words: \\ Storytelling, \\ Narrativity and Narrativity-Affecting \\ Features, \\ Narratee (Recipient), \\ Scheherazade, \\ The Thousand and One Nights
}

\begin{abstract}
Scheherazade's art of storytelling is the main vehicle for the fictional worldmaking in The Thousand and One Nights. The overall structure of the folktale narrative depends on the tales she recounts to King Shahriyar, and it is through these tales that she finally is able to change his mind. The richness of the narrative qualities, properties, and techniques in The Thousand and One Nights has attracted narrative scholars and narratologists for a long time. Besides applying the frame narrative as a basic narrative technique for storytelling practices, Scheherazade's tales include many other narrative aspects, including narrativity-affecting features. Narrativity generally refers to the qualities and features that cause a narrative to be accepted or evaluated as a (prototype) narrative. This paper argues that Scheherazade's first tale for the king Shahryar, "The Tale of the Merchant and the Ifrit," includes some narrativity-affecting features which have the potential to inspire its narratee's, Shahryar's, emotional and cognitive responses, and hence facilitate his transportation into the storyworld. By capturing his interest with her art of storytelling, Scheherazade is able to avert the king's heinous crime against herself.
\end{abstract}

\section{INTRODUCTION}

The abundance of thematic and structural properties in Alf Layla wa Layla ${ }^{l}$ has attracted a considerable degree of scholarly attention. In narratological approaches to this folktale narrative, its storytelling techniques, such as its "embedded" narrative or "frame" structure, its "temporal dimension" (Bal 2009: 5 and 78), and "the variety and ingenuity of [its] narrative forms" (Warner 2011: 9) have been highlighted. One of the main reasons such universal attention has been paid to The Thousand and One Nights is due to Scheherazade's art of storytelling.

Scheherazade is a professional storyteller. Empowered by her own reading experiences, she is well aware of storytelling practices and their impact on her audience. At the same time, she also understands the border between the fi tional and the real. ${ }^{2}$ By enchanting the king through her art of storytelling, she fulfils her goal of taking him out of his revenge-seeking world and postponing his crime against herself. In other words, as David Pinault says, "Scheherazade tries to word off this violence [the King's violence of threatening to kill her] by offering stories as ransom for her life" (1992: 9). ${ }^{3}$ She finally succeeds in changing his mind through both the tales she tells him and, more importantly, the way she tells them, or the manner of her narration. Along with the importance of the centrifugal structure of the narrative, the tales' narrative qualities contribute to both the king's and the reader's emotional and cognitive engagement during the tale. In this regard, Scheherazade's opening tale, "The Tale of the Merchant and the Ifrit" (also known as "The Merchant and the Genie"), carries out an important function, as it persuades the king to procrastinate killing Scheherazade so that he can listen to the next part(s) of the tale on subsequent nights. Therefore, Scheherazade succeeds in transporting the king to her fictional world. She does so mainly through the structural configuration of her narrative, which includes some narartivity-affecting features. This aspect of her storytelling, however, has not been studied so far.

\section{NARRATIVITY AS A CONSTITUENT ELEMENT OF NARRATIVE}

The concept of narrativity has a long history. In narrative studies, identifying the constitutive elements or the fundamental properties of narrative has always been one of the main concerns of narratologists. Narrative scholars do not agree on the exact definition of the term narrativity. ${ }^{4}$ It is a blurred, vague or, as Sonja Zeman holds, "a relational concept" (2). Depending on their schools, critics have defined narrativity based on either textual properties or the contex- 
tual ones or by the combination of the two. Therefore, "narrativity," according to Zeman, "cannot be defined by one single criterion but rather refers to a category that shares a variety of characteristic prototypical features" (3).

Narrativity, as defined by David Herman, refers to "what makes a story [interpretable as] a story" or "what makes a narrative a narrative" (2009: $x$ and 1). This concept, however, has undergone (re)definition over the years as the field of narratology has shifted. While the so-called structuralist, texualist, or classical narratologists tried to define narrativity mainly based on textual features and properties, the so-called contextual or postclassical narratologists paid attention to the defining role of the narrative receiver and the narrative's ability to stimulate a reader's cognitive responses. ${ }^{5}$

According to the narratologist Gerald Prince's definition of the term, although the narrativity of a text depends to some extent on its receiver's interest and evaluation, there are still some textual features whose presence in a text can enhance its narrativity level considerably. For example, a narrative text's structure and features, such as the temporal sequencing of events, their interconnected nature or wholeness, their thematic unification together with the existence of a conflict in the text's plot as well as a change of state from its beginning to its end all in all can increase its narrativity level.

Therefore, Prince's approach to the concepts of narrative and narrativity mostly focuses on the structural properties of a given narrative, although he states that the narrativity condition of a particular narrative is controlled by both the textual features of that narrative and by its receiver. Narrativity-affecting features, according to Prince, are numerous, ranging from the nature and order of the sequence of represented events to the narrative point (theme or object) and the narrative receiver's interest. He argues that narrativity-affecting features are both absolute and relative. Although one can think of some textual features-such as event sequencing, the discreteness or particularity of the represented events, their causal relationships, the conflicts brought about by them, their cohesion and wholeness, etc. (2004: 14; 1982: 145-161) - as narrativity-affecting factors, there are some other indeterminate features that can influence the narrativity of a text. Prince, therefore, tries to define narrativity by the help of what he thinks affects its condition and what does not. For example, he argues that:

Narrativity is not to be confused with textual value (one can find in a narrative much more than narrative or than narrativity: wit, imagery, psychological insight, philosophical vision, documentary information), it is also not to be conflated with the category of narrative appeal or narrative interest and, in particular, with a notion which pertains to that category and which has evoked a good deal of discussion. I am speaking of the notion »point . (2004: 15)

Likewise, the central theme in a narrative, or its controlling "point," can affect its narrativity level. Prince, however, argues that "point(edness) of a narrative or any other kind of text depends not only on the constituent features of those texts but also on the context." In other words, he thinks that "there is no link between narrativity and particular top- ics and themes" (2004: 16). In addition, Prince evaluates the relationship between narrativity of a text and its general narrative configuration

What narrativity seems primarily linked to is general narrative configuration (as opposed to specific thematic traits, contextual pointedness, or textual value). More particularly, it seems linked to the formal nature of the narrated (e.g., structural closure), that of the narrating (e.g., foregrounding of event discreteness) and the relations between the two (e.g., no inordinate amounts of commentary). (2004: 16)

Having reviewed all the possible narrativity-affecting features, Prince comes to the conclusion that none of them alone can determine the narrativity condition of a narrative: "even if the various features were ranked according to weight, there would still remain a sizable area of indeterminacy, given that some of them are "precise « or »absolute« whereas others are »fuzzy« or »relative«." Accordingly, he holds that the ongoing disagreements over the definition and characteristics of narrativity are quite reasonable and acceptable, since indeterminacy is "an integral and irreducible feature of narrativity" (2004: 17). Accordingly, Prince revises his earlier theory by stating that:

Rather than saying that, if a text exhibits features $x, y$, and/or $z$, it is endowed with a certain kind (or degree) of narrativity, one should perhaps say that if a text is thought to have a certain kind (or degree) of narrativity, it is because it is taken to involve $\mathrm{x}, \mathrm{y}$, and/or $\mathrm{z}$ (and because the latter are assigned a certain weight). (2004: 18)

Therefore, "the degree of narrativity of a given narrative," Prince holds, "depends partly on the extent to which that narrative fulfills a perceiver's desire by presenting oriented temporal wholes [...] involving a conflict, consisting of discrete, specific and positive situations and events, and meaningful in terms of a human(ized) project and world" (1982: 65). Accordingly, the concept of narrativity, as Prince understands it, is both definable and undefinable. He thinks that, despite some commonly known narrativity-affecting features, there are other features which are particular to a narrative's receiver: "the narrativity of a text depends on the extent to which that text fulfills a receiver's desire [.] Narrativity depends on the receiver and so does its value" (1982: 160). Since the same sequence of events, conflicts, general narrative configuration, etc. can appear differently to different people, the only "precise" and "absolute" feature of narrativity is a narrative receiver's appreciation of the narrative and its constituent features. Thus, a strict definition of narrativity, according to Prince, is difficult because some of its determining factors are variable, subjective, and relational.

Although Prince underlines the narrative receiver's crucial function in attributing narrativity to a particular text, he does not explain how the narrative receiver achieves this. His theory does not mention anything about the cognitive process of narrativity, or explore why some narratives appear to be more narrative-like to some receivers. Instead, he concludes that "many narratives are valuable not so much 
qua narratives but rather for their wit, their style, their ideological content, or their psychological insight" (1982: 160). This aspect of his theory has been criticised and modified by other narratologists. Monica Fludernik, for example, argues that 'Prince's definition [...] veers off into a number of tangents that trace this slippage from what narrative 'is' (with essential narrative 'features' attached) to what it 'does' to the receiver, and to the establishment of a scale of features that increase a text's narrativity" (2005: 234). Nevertheless, some of the narrativity-affecting features on which Prince grounded his textualist theory of narrativity can still be useful in the evaluation of a particular narrative's state of narrativity. As a good example, Scheherazade's first tale to Shahryar can be taken as the narrative hook of The Thousand and One Nights. With the help of a range of narrativity-affecting qualities, the tale has the potential to transport the king, as well as the reader, into the fictionally-situated world and persuade him to continue listening to the future tales. The tale can do this because of its features such as the sequence of events, their interconnectedness, their chronological and hierarchical organization, and their wholeness and pointedness, as well as the general narrative configuration ${ }^{6}$

\section{THE STATE OF NARRATIVITY IN SCHEHERAZADE'S OPENING TALE, "THE TALE OF THE MERCHANT AND THE IFRIT"7}

Scheherazade is the overt heterodiegetic narrator ${ }^{8}$ of her first tale to Shahryar. This first tale has a simple plot structure. It is the story of a merchant who goes away from home. He meets an Ifrit in a haunted spot who accuses the merchant of slaying his child by hitting it with one of the pits of the dates that he tossed away. The Ifrit threatens to kill the merchant and the merchant asks the Ifrit to let him go back home and say goodbye to his family and relatives. At the end of the year, the merchant returns to the Ifrit and is joined by three sheikhs who want to help him. The Ifrit reappears and wants to slay the merhcant. The first sheikh tries to dissuade the Ifrit from seeking revenge by telling a story about a gazelle. The tale ends when the Ifrit accepts the sheikh's offering by stating that, if he likes his tale, he will "grant" him "mercy for a third of this blood!" Scheherazade's tale primarily presents the sequence of events through action verbs.

The presentation of this sequence of events should be considered one of the most important narrativity-affecting features of Scheherazade's opening tale. The sequence has the power to engage the king cognitively and emotionally through the presentation of interconnected events. Scheherazade captivates the king's attention by narrating successive events. Her storytelling recounts interconnected events without including any additional details, descriptions, or commentary about them. As a result of the things she has read or her reading experience, Scheherazade is able to construct a persuasive narrative hook which transports the king into the storyworld to such an extent that he forgets the main point of their meeting. In this way, the opening tale acts as powerful magic by capturing the king's attention and persuading him to continue listening to the narrated events. This mostly happens through the narrative discourse or, more specificall, through the arrangement of the plot structure. The two-page tale cannot be thought of as anything other than a sequence of events which is, according to Prince, one of the main features that affects narrativity: "All other things being equal, for instance, a passage where signs of the narrated (referring to events) are more numerous than signs of the narrating (referring to the representation of events and its context) should have a higher degree of narrativity than a passage where the reverse is true" (1982: 146). "The signs of the narrated" in Scheherazade's opening tale are considerably more numerous than the "signs of the narrating." In other words, rather than explaining or developing the narrated events or intruding on them, Scheherazade focuses on the advancement or progression of the central point of the narrative plot. As a result, her opening tale changes into a presentation of precise events $^{9}$ that happened in a sequence.

The tale is made up of six parts or paragraphs. The first part is a preparatory or introductory paragraph in which Scheherazade sets the narrative scene by introducing the central character of her tale, "It has come to me, O auspicious King, that there was once a merchant of the merchants, master of many riches and of affairs of commerce in all lands" (Mathers 2005: 10). The succeeding five paragraphs are mainly made up of action verbs, and there are about 59 precise events in them. The authorial commentary and description, which has a lower effect on the narrativity level of a text than event reporting, is almost zero, as the events mainly describe the characters' states in different situations. The dominance of action verbs makes it difficult for the king either to think about the story or to think about what he should be doing. He has no other choice than to listen to the successive events. In this way, Scheherazade manages to capture the king's attention through narrating, rather than describing, ${ }^{10}$ the presented events. Her few descriptions are, moreover, in the service of her narration, as can be seen in the last part of the second paragraph (e.g. part 11 of footnote vii). Here, Scheherazade changes the narrative voice into the first-person narration in order to give some background information about the merchant. Such a perspectival change decreases the distance between the receiver and the storyworld, as its information is delivered immediately. These all add to the particularity and discreetness of the events and characters. For example, the narrative receiver can construct the merchant's character using the qualities ascribed to him. The tale, however, does not include more descriptive passages.

The events that make up the tale are, furthermore, all about one central conflict between the merchant and the Ifrit. Scheherazade builds up her storyworld based on the polarity of good and evil. The merchant stands for goodness, and the Ifrit represents the mysterious, dark, or evil side of humanity. For example, his reason for killing the merchant does not derive from any rational principle. The conflict between the merchant and the Ifrit acts as a central impetus for the progression of the narrative plot. The three sheikhs' successive appearances highlight the ongoing conflict even more. As the conflict increases, the king gets actively involved in the process of the events since, as a result of the presented narrative situation, he becomes involved in the narrative's 
moral decisions. The more details of the merchant's and the Ifrit's situation are presented, the more the king is engaged. The tale's frame structure involves him even more at it provides him with another chronologies of storyworld events.

Furthermore, the state of the conflict between the two perspectives, that of the merchant and that of the Ifrit, changes throughout the tale. While the Ifrit intends to slay the merchant at the beginning, he shows some flexibility in deciding to forgive him at the end of the tale just before listening to the first sheikh's story. The appearance of the three sheikhs in the middle of the tale affects and reconstructs the increasing conflict between the merchant and the Ifrit. The first sheikh's proposal has a teleological function in the plot structure as it raises the hope, in both the king and the reader that the Ifrit finally will forgive the merchant by the end of the third sheikh's story. Therefore, the change of state between the tale's beginning and its end can be understood mainly because of what happens in the middle.

The successive events in Scheherazade's opening tale, furthermore, are all about the same narrative theme or object and focus on a shared object of narration. The wholeness of the events and their pointedness, which are the narrativity-affecting features, increase the king's engagement in the narrative. Scheherazade's narration, therefore, is capable of capturing the king's attention by using short sentences, interconnected action verbs, no intrusive comments, and a central conflict and theme. Scheherazade's storytelling skills and the basic features of her narrative persuade the king to postpone his vicious crime against her, and finally fo get about it.

\section{CONCLUSION}

Scheherazade is represented as a professional storyteller in her opening tale for Shahryar. She uses storytelling as a way to treat the king's psychological trauma. Every woman reminds Shahryar of his wife's disloyalty, and Scheherazade's first tale acts as the first session of a counselling treatment plan. She builds up a world of crime and revenge that is suitable for her patient. Her tale immediately becomes a process of persuasion. The merchant and the three sheikhs try to persuade the Ifrit to stop seeking revenge, and the Ifrit shows some flexibi ity towards the end of the tale. In this way, Scheherazade indirectly draws a parallel between the fictional situation of the tale and the real one she is situated in. Additionally, Scheherazade tries to control and guide the king's behaviour through her discourse. Relying on her own skill and capacities, she dares to go to his court and offer both her body and life to him. Her familiarity with fictional worlds enables her to persuade the king to procrastinate his planned crime. She is able to do so both because of what she tells him and how she tells it. On the one hand, she bases her story on a sound conflict between good and evil, and arranges all events around this polarity. On the other hand, she avoids any authorial-narratorial commentary or intrusion, as well as any unnecessary descriptions. Accordingly, the tale's narrative unity inspires the king's cognitive responses and increases his involvement in the narrative world. In this way, he is persuaded to continue listening to the following embedded narratives, and the more he listens the more he forgets about his primary intention.

\section{ENDNOTES}

1. This original Arabic title is known to English readers as the Arabian Nights, (the Tales of) A Thousand and One Nights or The Thousand and One Nights. The last name is used throughout this essay.

2. The heterodiegetic narrator, or a narrator who is not a character in the story, points out this aspect of Scheherazades character in this way: "Shahrazad had read the books, the annals, and the legends of old kings, together with the histories of past peoples. Also she was credited with possessing a thousand books of stories telling of the peoples, the kings, and the poets of bygone ages and of past time. She was sweetly eloquent of speech and to listen to her was music" (Mathers 2005: 6).

3. When King (Sultan) Shahryar finds out that his beloved wife has betrayed him, he comes to the conclusion that all women are evil and untrustworthy. So, he decides to marry a different maiden every morning and have her head cut off after the wedding night. Scheherazade (also known as Shahrazad) proposes that her wazir father marry her to the king. When she sees the king, she just makes one request. She asks him to let her to tell a story to her younger sister, Dunyazad, in the late evening. Her storytelling practice to the king begins from the moment he hears the first story, "The Merchant and the Ifrit," which she tells to her sister.

4. As the narratologist John Pier states, narrativity is a complex issue since it addresses many questions without definite answers, such as

Can narrativity be defined by its formal features? Is it one narrative category among others? Are there types of narrativity? degrees of narrativity? Do narratives possess narrativity or do they exhibit narrativity? Do they produce narrativity or are they produced by narrativity? Does narrativity in, say, a novel differ from narrativity in a short story or a film? Can narrativity be perceived in different ways? (2008: 109).

5. In this group, Marie-Laure Ryan, Monika Fludernik, and David Herman mostly pay attention to the narrative receiver's role in the narrativity level of a particular narrative.

6. Despite the structural differences among the various English versions of the tales of The Thousand and One Nights (Reynolds 2008: 270-291), the basic narrative features of Scheherazade's opening tale remain more or less the same.

7. The numbers in the tale below show events and their types-Actions and Happenings:

(a) [1.] One day he mounted on horseback and [2. he] left for certain places whither his business called him. [3. a: (Happening):] As the heat became too vexing, [3. b: (Action or Act):] he sat down under a tree and, [4. a:] putting his hand into his food-bag, [5. b: (he)] took from it a snack and also some dates. [6.] When he had finishe eating the dates, [7.] he threw the stones to a distance; [8.] but suddenly an enormous Ifrit appeared who approached him, [9.] brandishing a sword and [10. he was] crying, '[a.] Rise up, [b.] that I may slay you as you have 
slain my child!' On this the merchant asked: 'How have I slain your child?' [c:] The other said: 'When you threw the stones of the dates you had eaten, [d: (Happening)] they struck my boy in the breast and [e:] he died forthwith.' [11.] Then said the merchant to the Ifrit: 'Know, O great Ifrit, that I am a Believer and know not how to lie. Now I have many riches and children and a wife, also I have at my home deposits which have been trusted to me. Give me leave to go to my house that I may render each his due and, when I have done this, I will return to you. Indeed, indeed, you have my promise and my oath that I will return to you forthwith. Then you shall do to me as you wish. And Allah is a witness of my words.' So the Jinni had trust in the merchant and let him depart. (b) [12] The merchant returned to his own land, [13] rid himself of his obligations, [14] rendered each his due, [15] and lastly revealed to his wife and his children the fate that had overtaken him. [16] So they all, relations, women and children, began to weep. [17] Then the merchant made his will and rested with his folk until the year's end; [18] after which, taking his winding-sheet beneath his arm, [19] he bade farewell to his nearest, to his neighbours, and to the folk of his house, [20] and went forth, as it were, in spite of his nose. [21] Then indeed was lamentation made and grief cried over him. (c) [22] As for the merchant, he continued to journey until he came to the garden where he was due on the first day of the new year. [23] Now, while he sat down [24] to weep over his fate, [25] behold a venerable sheikh came towards him [26] leading a gazelle by a chain. [27] $\mathrm{He}$ saluted the merchant, [28] wishing him a life of prosperity [29] and saying to him: 'What is the reason of your staying alone upon this Jinn-haunted spot?' [30] Then the merchant told him of his adventure with the Ifrit. [31] And the sheikh, master of the gazelle, being greatly astonished, [32] said: 'By Allah, your faith, my brother, is indeed a rare faith! And your story is so prodigious that, were it only written with a needle on the inner corner of an eye, it would yet be a matter of reflection to the circumspect.' [33] Then he sat down by the merchant's side, [34] saying: 'By Allah! I shall certainly stay here with you, my brother, until I have seen what happens between you and the Ifrit.' [35] So he stayed, [36] conversing with the merchant, [37] and beheld him swooning with fear and horror, a prey to deep sorrow and to stormy thoughts. [38] Suddenly, as the master of the gazelle waited, there came a second sheikh, [39] who advanced towards them leading two dogs of greyhound breed which were both black. [40] He came up to them, wishing them peace [41] and asking the reason of their stay upon that Jinn-haunted spot. [42] So they told him the story from beginning to end. [43] But hardly had he seated himself, [44] when a third sheikh came towards them, [45] leading a bay-coloured shemule, [46] and he also wished them peace [47] and asked them the reason of their stay. [48] Again they told the story from beginning to end; but nothing is to be gained by repeating it in this place. (e) [49] In a little while a sand-devil lifted and a great wind blew heavily, coming towards the middle of the grassland. [50] Then, the dust dispersing, [51] the selfsame Jinni appeared, a fine-sharpened blade in his hand and sparks of fire storming from his eyes. [52] He came to them and, seizing the merchant from among them, [53] said: 'Come, that I may kill you as you killed my child, who was the breath of my life and the fire of my heart.' [54] Then the merchant began to weep and lament, [55] and the three sheikhs also set themselves most conspicuously to weep and groan and sob.

(f) [56] But the first sheikh, master of the gazelle, at last plucked up his courage [57] and kissed the hand of the Jinn, [58] saying: 'O Jinni, O chief among the Kings of the Jinn and their crown also, if I relate to you the tale of myself and this gazelle and it is such that you marvel at it, oh grant me in return mercy for a third of the blood of this merchant!' [59] The Jinni answered: 'Assuredly, $\mathrm{O}$ venerable sheikh. If you tell me the story and I find it indeed extraordinary, I will grant you mercy for a third of this blood! (Mathers: 2005: 10-11)

8. Compared to the homodiegetic narrator, or a narrator who is a character in the story as well, heterodiegetic or authorial narrator is not a character in the story or remains outside of it.

9. Prince defines an event as "a change of state manifested in discourse by a process statement in the mode of Do or Happen. An event can be an Action or Act (when the change is brought by an agent: 'Mary opened the window') or a Happening (when the change is not brought about by an agent: 'the rain started to fall'). Along with existents, events are the fundamental constituents of the STORY" (2003: 28).

10. Description, according to Herman, is "a kind of text or discourse (i.e., a text type) core instances of which ascribe properties to situations, objects, and events, whether statically (as in That cat is elegant) or dynamically (as in Tuesdays and Thursdays I eat cereal for breakfast and on other days I eat toast and jelly)" (2009: 183). Herman, however, believes that the other text types such as describing and explaining can support the narrating element of a given narrative: "From a microanalytic perspective at least, narrative sequences can be conceived as building additional structure on foundations provided by the elements contained in descriptive sequences" (2009: 102).

\section{REFERENCES}

A Dictionary of Narratology (Revised Edition). Nebraska: University of Nebraska Press, 2003.

Bal, Mieke. Narratology: Introduction to the Theory of Narrative. $3^{\text {rd }}$ ed. Toronto: University of Toronto Press, 2009.

Fludernik, Monika. Towards A Natural Narratology. London: Routledge, 2005.

Herman, David. Basic Elements of Narrative. Chichester: Wiley-Blackwell, 2009.

Mathers, Powys. The Book of the Thousand Nights and One Night. London: Routledge, 2005. 
Pier, John. "After this, therefore because of this." Theorizing Narrativity, edited by Pier John and José Ángel García Landa. Berlin: Walter de Gruyter, 2008, pp. 109-140.

Pinault, David. Story-Telling Techniques in the Arabian Nights. Leiden: E. J. Brill, 1992.

Prince, Gerald. "Revisiting Narrativity." Narrative Theory: Critical Concepts in Literary and Cultural Studies, edited by Mieke Bal. London: Routledge, 2004, pp. 11-19.

Narratology: The Form and Functioning of Narrative. Berlin: Mouton Publishers, 1982.

Reynolds, Dwight F. “A Thousand and One Nights: a history of the text and its reception." The Cambridge History of Arabic Literature: Arabic Literature in the Post-Classical Period, edited by Roger Allen and D. S. Richards, Cambridge University Press, 2008, pp. 270-291.

Warner, Marina. Stranger Magic. Charmed States and the Arabian Nights. London: Chatto \& Windus, 2011.

Zaman, Sonja. "Introduction: Perspectives on Narrativity and Narrative Perspectivization." Perspectives on Narrativity and Narrative Perspectivization, Natalia Igl and Sonja Zeman, John Benjamins Publishing Company, 2016, pp. 1-14. 